\title{
SUPPLIER STRATEGY IN GLOBAL VALUE CHAINS: \\ SHAPING GOVERNANCE AND PROFITING FROM UPGRADING
}

\author{
Mari Sako \\ Professor of Management Studies \\ Saïd Business School \\ University of Oxford \\ Park End Street \\ Oxford, OX1 1HP, UK \\ $\mathrm{Tel}+44(0) 1865288925$ \\ Email: mari.sako@sbs.ox.ac.uk \\ Ezequiel Zylberberg \\ Postdoctoral Associate \\ Industrial Performance Center \\ Massachusetts Institute of Technology \\ 400 Main St., Building E19-733 \\ Cambridge, MA 02139 \\ Tel +1(617)258-6138 \\ Email: ezylber@mit.edu
}

This draft: October 2017

Comments welcome

Acknowledgements: We thank Greg Distelhorst, Mai Fujita, John Humphrey, Ding Ke, Renato Lima de Oliveira, Hiram Samel, Tim Sturgeon, Marc Szepan, Eric Thun, and the anonymous reviewers for their helpful comments and suggestions. We also thank the participants of the Global Value Chain Network of the Society for the Advancement of Socio-Economics (SASE) at the Annual Conference held at the London School of Economics in July 2015 for feedback on an earlier version of this paper. 


\title{
Supplier Strategy in Global Value Chains: \\ Shaping Governance and Profiting from Upgrading
}

\begin{abstract}
The growth of emerging market firms with a global presence highlights the need to better understand how supplier strategy influences global value chains (GVCs). We respond to this need by applying corporate strategy and technology strategy to improve the predictive and prescriptive power of GVC theory. Under what circumstances can suppliers in GVCs shape governance and profit from upgrading? Using corporate strategy, we argue that supplier strategy concerning make-or-buy decisions and buyer diversification can effect a change in governance mode. Using technology strategy, we identify appropriability regimes and complementary assets as essential pre-conditions for suppliers capturing value from upgrading. Our central contribution is in developing an integrative theoretical framework for analyzing how suppliers alter governance over time, and how they capture the value they create by upgrading, resulting in shifts in value chain polarity. This framework has significant implications for economic development.
\end{abstract}

SER Keywords: firm strategy, management, governance, innovation, outsourcing, economic development

JEL Keywords and Codes: Firm Objectives, Organization, and Behavior, General (L20), Economic Development, General (O10), Innovation; Research and Development; Technological Change; Intellectual Property Rights, General (O30) 


\section{INTRODUCTION}

The geographic dispersion of productive activities into global value chains (GVCs) has spread from agriculture and manufacturing to services, including business and knowledgeintensive services such as R\&D. Furthermore, international trade and foreign direct investment flows are increasingly shaped by companies headquartered in emerging markets. Some emerging market giants like Bharat Forge, Foxconn and Li \& Fung participate in GVCs as suppliers and intermediaries (Appelbaum, 2008). Others drive GVCs by virtue of being brand-owning producers (e.g. TCL, Xiaomi, Embraer) working with suppliers from industrialized countries (e.g. Schlumberger, Bosch, GE) to sell goods and services beyond their home markets (Brandt \& Thun, 2011; Gereffi, 2014; Ramamurti \& Singh, 2009; Sako, 2011; Sturgeon, Humphrey, \& Gereffi, 2011; Sturgeon \& Lester, 2004). Gone are the days when lead firms hailed only from developed economies, and suppliers hailed only from developing countries.

The international expansion of emerging market suppliers and the growth of emerging market buyers dependent on the global supply base highlight the need to develop a better theoretical understanding of how supplier strategy shapes GVCs. This paper furthers this cause by demonstrating the value of using management theories - corporate strategy and technology strategy in particular - to develop a robust theory of supplier strategy in GVCs. We pay attention to a combination of supplier strategy and exogenous shifts in structural constraints. This focus enables us to identify the conditions under which suppliers can actively alter existing value chain dynamics in the face of either sustained or changing structural constraints. Such analysis has important implications for economic development in the global south.

In presenting the definitive theory of global value chain (GVC) governance, Gereffi, Humphrey, and Sturgeon (2005) link the question of who controls globally fragmented production chains to certain transactional characteristics. The three characteristics (transactional complexity, codifiability of information, and supplier capabilities) determine how relationships are governed, with governance modes ranging from hierarchy, with a lot of power accruing to the lead firm, to market, which implies a more equal power distribution. The literature has made few forays into the issue of whether or not suppliers are able to change the prevailing balance of power in value chains. Gereffi and colleagues (2005) state that value chain governance is determined, in part, by supplier capabilities.

Lead firms could not externalize key functions in the first place if suppliers with the internal capabilities necessary to take them on did not exist. For suppliers, building the 
capabilities necessary to internalize specific transactions is fundamental to participation in GVCs. In this paper, we draw a distinction between a supplier's ability to internalize a given transaction, and its decision to do so. Capabilities are necessary but alone insufficient for effecting shifts in value chain governance. We also seek to uncover the ways in which suppliers may capture value even if their capabilities are not idiosyncratic in themselves, in particular by controlling or accessing complementary assets. This paper imbues GVC suppliers with agency by asking two interrelated questions. Firstly, how do suppliers deviate from established forms of governance? And secondly, under what conditions can they capture value from upgrading? We argue that the role of suppliers has been under-theorized thus far, and that providing answers to these questions would raise the GVC framework's predictive and prescriptive power.

In this paper, we build on Gereffi and colleagues (2005)'s framework to identify the conditions under which suppliers can reshape governance and capture more value over time. To do so, we bring management theories to bear on the GVC framework. We begin this task with the notion of GVC governance. Respectful of its origin in world-systems theory to analyze commodity chains, GVC research has gently pushed the level of analysis from a worldwide capitalist logic of labor process towards a more firm-centered conceptualization. And yet, whether it is two types (producer-driven vs. buyer-driven) (Gereffi \& Korzeniewicz, 1994) or five types (Gereffi et al., 2005), the analysis of governance has privileged industrylevel norm setting at the expense of firm-level strategy. Whilst efforts have been made to unpack governance as driving, linking, and normalizing (Gibbon, Bair, \& Ponte, 2008), and to identify a plurality of driving mechanisms at micro and macro levels of GVC governance (Ponte \& Sturgeon, 2014), the existing frameworks do not elaborate on corporate strategy sufficiently. Lead firms, with the aid of standard setting bodies and international institutions, may settle upon certain modes of governance. But we argue and theorize that suppliers can deviate from them to varying degrees, not only by investing in their capabilities but also by choosing with which client firms they work.

We next delve into the concept of upgrading. On the one hand, many have argued that suppliers can make gains by upgrading to higher value activities, sectors, products and processes (Humphrey \& Schmitz, 2002). On the other hand, some have pointed out that firms fail to capture the value they create through upgrading because of low barriers to entry and rapid diffusion of upgrading practices (Mahutga, 2014; Schrank, 2004). The result is an unfavorable distributional outcome for the upgraded supplier and 'immiserizing growth' for the developing country in which it is situated (Kaplinsky, 2000; Kaplinsky \& Morris, 2001). 
We focus our efforts on identifying the circumstances under which value creation leads to value capture for the supplier undertaking upgrading. This issue of firm-level value capture is not fully addressed by GVC scholars. Neither is it addressed fully by Global Production Network (GPN) scholars, although they do discuss value capture at the regional level (Coe \& Yeung, 2015; Henderson, Dicken, Hess, Coe, \& Yeung, 2002). We challenge the assumption that suppliers generally gain (or lose) from upgrading by employing Teece's (1986) 'profiting from innovation' framework, which analyzes the reasons why firms may sometimes create value but fail to capture it. We specify the conditions under which suppliers' upgrading efforts enable them to extract greater rent vis-à-vis their client firm, thus transforming the distribution of power in a value chain. These conditions apply also to complementors that develop products and services using a platform (Gawer, 2009; Gawer \& Cusumano, 2002).

Gereffi and colleagues (2005) have persuasively argued that value chain governance is partially determined by supplier capabilities. In our framework, we augment this insight and argue that suppliers exercise discretion not only over which capabilities to internalize, but also which client(s) to work for. These strategic decisions on the part of suppliers influence how inter-firm relationships are governed. Further, under some circumstances, firms are able to capture the value they create by investing in upgrading. In these cases, we may see a shift in who drives the GVC, in other words, value chain polarity. In short, our main contribution is the development of an integrative theoretical framework to explain how suppliers alter the forms of governance to which they are subject, how they capture the value they create by investing in upgrading, and ultimately, how their actions produce changes in value chain polarity. To be clear, our unit of analysis is the firm, in particular, the supplier. This is not to ignore the fact that power in GVCs accumulates unevenly, and that value chain polarity may shift, sometimes towards multi-polar governance (Ponte \& Sturgeon, 2014), for reasons other than firm-level strategy. Of course, there exists a broad constituency of actors seen to be consequential in GVCs, leading to a reinterpretation of power beyond the market arena (Ponte, 2014). International and national institutions matter in providing constraints on the scope of supplier strategy (Coe \& Yeung, 2015; Peng, Wang, \& Jiang, 2008). But in the spirit of modular theory-building (Ponte \& Sturgeon, 2014), we focus on supplier strategy, which can yield important insights into how firm-level choices impact governance, value capture and value chain polarity in the face of sustained or changing structural constraints.

The paper is structured as follows. Section 1 reviews the essence of GVC theory and identifies the gaps that our paper seeks to address. Section 2 brings the concepts of governance and upgrading into communion with corporate strategy and technology strategy, 
respectively, with the intent of improving the predictive and prescriptive power of the GVC framework. Section 3 presents an integrative theoretical framework that accounts for how suppliers' strategic decisions influence governance and lead to value capture from upgrading. Section 4 discusses the utility of this framework by interpreting empirical evidence from a range of industries. Empirical evidence also clarifies the scope conditions for the applicability of our theoretical framework. We then conclude by reasserting our thesis, that management theories can improve the predictive and prescriptive power of the GVC approach.

\section{GLOBAL VALUE CHAIN RESEARCH: THEORETICAL ACHIEVEMENTS AND GAPS}

In their seminal work, Gereffi and colleagues (henceforth GHS (2005)) seek to identify the transactional characteristics that predispose firms in an industry to adopt a specific mode of governance. GHS (2005) develop a typology with five modes of governance: market, modular, relational, captive and hierarchy. These modes are influenced by three characteristics of transactions: the complexity of information exchange, the codifiability of knowledge, and the supplier's capabilities. On the far ends of the scale lie the classic opposites of market and hierarchy, the latter referring to linkages between in-house operations (Williamson, 1975). Between the two extremes lie three network forms of coordination ranging from 'modular' on the market-like end of the scale, where complex information is codified; to a 'relational' form of governance in the center, involving the exchange of tacit knowledge and governance by trust and reputation; to a quasi-hierarchical 'captive' form that is more akin to vertical integration.

This framework has proven useful for characterizing linkages in various industries (Berger, 2013; Berger \& Lester, 2005; Sturgeon, Van Biesebroeck, \& Gereffi, 2008; Sturgeon \& Kawakami, 2011; Tran, Bailey, Wilson, \& Phillips, 2013). GHS (2005) illustrate with a number of empirical vignettes. In the automotive industry, governance moved away from 'hierarchy' towards 'modular' when lead firms sought to lower costs and risks through outsourcing. However, even with the rise of global component suppliers, attempts to drive towards 'modular' governance were thwarted by poor industry standards and difficulty in modularizing the design and manufacture of a complex product. Governance in the apparel industry shifted from 'market' toward 'relational.' Whereas in the past, labor contractors in low wage locations had carried out highly standardized sewing operations, more recently, intermediaries such as Li \& Fung have grown by offering brand-owning clients a range of sophisticated services including supply chain management, rapid order fulfillment, and 
materials sourcing. Various empirical studies have demonstrated that shifts in governance can be tied to changes in the three transaction characteristics that form the core of the GVC framework (for example, see Schmitt and Van Biesebroeck (2016)).

The goal of GVC research has been both analytical and prescriptive. In advancing theory, it aims to develop tools for characterizing the complex and dynamic process of globalization (Gibbon et al., 2008). Ontologically and epistemologically, GVC researchers have characterized GVCs largely on the basis of rich, interview-based case studies. In GHS (2005), however, GVC theory moved decisively towards deduction, providing greater predictive power through parsimonious theorizing. The increased emphasis on parsimonious theorizing has been perceptible in more recent work as well. For example, building on the idea that 'barriers to entry are the determinants of the distribution of rents' (Kaplinsky, 2000, pp. 127), Mahutga (2014)'s 'exchange theoretic' conceptualization of inter-firm power asymmetries sheds light on why and how lead firms extract concessions from their suppliers.

The extent of parsimony chosen, however, has led to an anemic conception of some important elements of the GVC framework. By theorizing in ways that are deterministic across value chains but probabilistic for specific value chains, Mahutga (2012) does not uncover the causal mechanisms behind important exceptions that deviate from the norm (pp.17-18). We argue that a theoretical explanation for these exceptions is needed. Schrank (2004) analyzes firm-level data in the Dominican Republic and concludes that in general, apparel suppliers are upgrading to full-package production in the Caribbean basin, but that the returns to upgrading diminish because it is so easy to imitate this practice. But on closer examination, how would one explain the relative success of some full-package producers over others? Kaplinsky (2000) admits that 'the focus on the dynamics of rent also requires inputs from management studies and engineering' (p.129-130), where firm-level analysis is possible and commonplace. The model we propose gives GVC scholars the tools to understand why and how rent and value capture might arise. Understanding why some firms capture value while others do not has important implications for suppliers and more broadly for territorial economic development. As Coe and Yeung (2015) state, 'value capture...is the most important dimension in developmental terms' (p.171).

In the spirit of Ponte and Sturgeon (2014)'s call for modular theory building, and keeping in mind the advantage of parsimonious theorizing, we use management theories to improve the predictive power of the GVC framework. Specifically, we propose that suppliers can actively shape governance modes under certain circumstances; they do not simply maneuver within pre-ordained constraints. A supplier faces a choice to a varying degree in 
how it manages its boundaries and how it structures its buyer portfolio. These choices are distinct from those that determine the quality of a supplier's capabilities. Choices regarding firm boundaries and buyer portfolio can impact a supplier's power vis-à-vis its buyer(s). In addition, when legal and technical appropriability regimes are weak, suppliers can profit from upgrading only if they control a specialized complementary asset critical to their clients. Building on the realization that economic globalization is an artifact of corporate strategy (Gereffi 2014, p.455), we clarify the micro-foundations of power distribution in GVCs so that critical questions about supplier strategy and value capture at the firm level might be addressed.

\section{INCORPORATING MANAGEMENT THEORIES INTO GLOBAL VALUE CHAINS}

Our aim is to respect the existing goals of GVC research, and to broaden the utility of the GVC framework by incorporating robust theories about strategic choice. We select two areas of management studies which theorize about such choice: first, corporate strategy which involves decisions about firm boundaries and buyer portfolio, and second, technology strategy which considers how firms profit from innovation. We employ these two areas in particular because they allow us to make theoretical headway towards answering two important questions: how do suppliers shape governance, and how do they capture the value they create through upgrading? We wish to understand the effect of managerial discretion on supplier power, and the field of management studies provides the tools necessary to do so. This section is in two parts. The first part addresses how incorporating corporate strategy improves GVC governance theory, and the second employs technology strategy to clarify the link between value creation and value capture.

\subsection{Supplier strategy and GVC governance}

Governance prevails both for the whole value chain in an industry - or industry architecture (Jacobides, Knudsen, \& Augier, 2006) - and for the dyadic transaction between a buyer and a supplier (Williamson, 1985). Recent work on GVC governance recognizes the importance of firm-level agency, specifically that of lead firms that drive the process of disintegration, reintegration and geographic dispersion of production (Ponte \& Sturgeon, 2014). For lead firms, governance is about driving, linking and normalizing (Gibbon et al., 2008). However, the existing GVC frameworks do not give sufficient attention to corporate strategy for non-lead firms. Our focus is on how suppliers navigate the constraints set by lead firms and other non-firm actors and institutions. The dynamic nature and geographic 
variability of the broader institutional constraints that govern global value chains and global production networks are already well elaborated (Coe \& Yeung, 2015). This enables us to concentrate on the task of elaborating on supplier strategy in GVCs, noting that broader institutional constraints also influence supplier strategy.

Although value chain governance is largely determined by transactional characteristics and lead firms' externalization choices, we argue that suppliers do make strategic decisions about what to make in-house and what to buy, and the number of buyers to which they supply. For instance, a supplier relying heavily on a sole client (in captive governance) may scale production or internalize higher value adding activities such as design, shifting towards relational governance, or codify its work in an effort to make it available to alternative buyers (thus moving toward modular governance). As a starting point for inter-firm level analysis, GHS (2005)'s three transactional characteristics (informational complexity, knowledge codifiability, and supplier capability) predispose buyer firms to adopt a particular governance mode. This GVC theory privileges the three transactional characteristics as parameters to be taken into account for a buyer's governance decisions. At the same time, the transactional characteristics become structural constraints for suppliers (Gibbon et al., 2008). The question is whether or not there is scope for suppliers, rather than buyers, to change these structural constraints. Without this consideration, it is difficult to see how GHS (2005) can make predictions other than the functionalist implications drawn from transaction cost economics (Williamson, 1985).

One way of turning structural constraints into decision variables is to theorize how make-or-buy decisions influence governance modes, which is the original intent of transaction cost economics (Williamson 1985). Unfortunately, GHS does not allow for this because their theory takes a two-step approach in which firm boundaries are fixed first before governance modes are chosen. In effect, GHS (2005) allows for a theory of externalization to explain the emergence of GVCs, but not a theory of internalization subsequent to the establishment of GVCs. Make-or-buy decisions are generally influenced by considerations of transaction costs (Williamson, 1985), contractual incompleteness (Gibbons, 2005), capabilities of the ordinary and dynamic sorts (Prahalad \& Hamel, 1990; Teece, 2014b; Teece, Pisano, \& Shuen, 1997), and institutional distance (Pache \& Santos, 2010; Xu \& Shenkar, 2002). In the GVC context, GHS (2005) embeds its framework in a combination of transaction cost economics and ordinary capabilities theory with supplier capability as one of the three variables. By developing the concept of capabilities further and paying attention to 
the distribution of capabilities in GVCs (Jacobides, 2008), GHS (2005) could incorporate a theory in which make-or-buy decisions by suppliers affect governance modes.

For example, suppliers might develop the capabilities necessary to carry out high value-adding activities, for example taking on design as well as assembly. Internalizing design potentially increases a supplier's bargaining power vis-à-vis its buyer(s), assuming design capabilities are not widely available in the supply base. Relative bargaining power in turn affects transactional governance (Argyres \& Liebeskind, 1999). As Mahutga (2012) and others have argued, lead firms internalize activities subject to high entry barriers in which they have a competitive advantage. We turn this proposition on its head, suggesting that some suppliers might internalize certain activities (e.g. design) as a step towards raising barriers to entry, thus effecting a shift value chain polarity.

Furthermore, a supplier could enhance its bargaining power by supplying many buyers rather than a few buyers, thus effecting a shift away from captive governance. Suppliers' choice is enhanced if they seek to diversify buyers in different industries and geographic locations. Moreover, GHS (2005) appears to apply the captive governance form to a dyadic linkage between a multinational buyer corporation as a whole and a single-plant supplier company. However, when the supplier is also a multinational with a global footprint (Appelbaum, 2008; Sturgeon et al., 2011; Sturgeon \& Lester, 2004; Whittaker, Zhu, Sturgeon, Tsai, \& Okita, 2010), the resulting bilateral monopoly may create indeterminacy in governance. Specifically, it is unclear how a dyadic linkage between an emerging-market lead firm and a tier one supplier from an industrialized country would be governed. Thus, as Ponte and Sturgeon (2014) note, when both suppliers and buyers are global, the industry value chain might become multipolar rather than unipolar. We identify one cause of such multi-polarity in suppliers' strategic choice over their firm boundaries and buyer portfolios.

\subsection{Capturing value from upgrading}

The challenge of upgrading by developing country producers has long been a major concern for GVC researchers. Gereffi (1999) conceived of industrial upgrading as a multidimensional process observable at various levels of analysis, including factories, interfirm networks, localities, regions and countries. Drawing on this work, Humphrey and Schmitz (2000a, 2002) outline an upgrading typology, elaborating how firms in clusters take on more advanced processes (i.e. improving process efficiency), products (i.e. providing higher quality goods and services), functions (i.e. changing the mix of value adding activities), and sectors (i.e. moving into different industry sectors). This upgrading typology 
has been employed across a range of empirical settings, including the footwear cluster in Brazil's Sinos Valley (Bazan \& Navas-Alemán, 2004; Schmitz, 1999), the apparel cluster in Torreon, Mexico (Bair \& Gereffi, 2001) and the electronics industry in Taiwan (Guerrieri \& Pietrobelli, 2004).

The notion of industrial upgrading emerged to demonstrate that participation in GVCs could create pathways towards better livelihoods for people in developing countries. Nowhere is this idea more clearly articulated than in the 'smiling curve' first proposed by Acer's founder, Stan Shih, in the early 1990s (Mudambi, 2007). The smiling curve of value creation demonstrates that value added is highest at the extreme ends of the value chain (R\&D on one end and marketing and after-sales service on the other) and lowest in the middle (manufacturing). But the GVC literature has never satisfactorily resolved the disjuncture between value creation and value capture, sometimes assuming that the two go hand in hand. On the one hand, upgrading is assumed to protect suppliers by raising barriers to entry (Bair \& Gereffi, 2001; Gereffi, 1999). On the other, some scholars have long argued that participating in GVCs can place developing countries in a proverbial race to the bottom, condemning them to 'thin industrialization', 'immiserizing growth' or 'downward harmonization' in wages and working conditions (Kaplinsky, 2000; Schrank, 2004). In this interpretation, firms invest in upgrading, but fail to capture the profits generated. Here, upgrading (without value capture) is the price suppliers must pay for GVC participation. As pointed out by Tokatli (2013), 'simply entering into a higher value-add activity does not guarantee the capture of additional value' (p.1000). The question then remains: under what circumstances does upgrading or downgrading lead to suppliers capturing a greater share of the aggregate profit created?

The question remains unanswered in part because the primary unit of analysis in the literature on industrial upgrading is the cluster, the industry, the region, or the nation (Giuliani, Pietrobelli, \& Rabelotti, 2005; Humphrey \& Schmitz, 2000b; Tewari, 2008). This leaves little room for theorizing about how firm-level decisions affect value capture by the firm. Coe and Yeung (2015) go a long way to identify this limitation, noting that only by focusing on the intersection of an individual firm with a single global production network as the basic unit of analysis can we begin to understand firm-level value capture trajectories (pp.170). But they frame value capture in terms of territorial economic development, and does not discuss firm strategies to achieve this desired end. Dedrick, Kraemer, and Linden (2009) begin to address this issue by demonstrating that Apple commands high profit margins because it controls its operating system, applications ecosystem, proprietary standards and 
brand. By contrast, its manufacturing partners capture little of the value they create because manufacturing is subject to low entry barriers. Building on this important work, we recommend a systematic examination of how technology strategy enables firms to profit from upgrading.

The 'profiting from innovation' framework seeks to qualify the correlation between innovation and competitive advantage by challenging the belief that innovators always profit from being first movers (Teece, 1986). Upgrading can be characterized as one type of innovative activity. Whether or not the innovator profits depends on three key factors. The first is the appropriability regime in which the innovator and potential imitators operate. This refers to barriers against imitation arising from the intellectual property rights regime in place. The regime is location-specific, and is one aspect of national institutions that impact supplier strategy (Peng et al., 2008; Scott, 2001). The second factor is whether the product or service finds itself in the pre-paradigmatic or in the paradigmatic stage of technological development (Abernathy \& Utterback, 1978; Geroski, 2003). Once an industry coalesces around a dominant design, followers begin to compete on price, thus eroding the advantage earned by the innovator. The third factor is access to complementary assets. Innovators leverage control over assets such as complementary technologies, distribution channels and logistics networks to capture more value from their investments.

Complementary assets become more important for profiting from innovation the weaker the appropriability regime and the more established the technological paradigm. Some complementary assets are more valuable than others. Generic complementary assets are a poor source of competitive advantage. Ports, canals, airports, roads, and a wide range of information and communication technologies are public goods, which no firm can be excluded from using. By contrast, specialized complementary assets are characterized by unilateral or mutual dependence, for example specialized manufacturing capabilities or a sales and service network controlled by a supplier on behalf of its buyer (Tripsas, 1997). Cospecialized complementary assets are characterized by mutual dependence, for example, the relationship between pharmaceutical drug production and the regulatory expertise necessary to push drugs through the clinical pipeline (Pisano, 2006). The value of a given complementary asset depends on how critical it is to the innovator's ability to generate revenue.

As Jacobides and colleagues (2006) have argued, firms benefit by investing in complementary assets that appreciate in value. A restaurateur may choose to focus on the downstream segment of the value chain, creating a concept and managing the restaurant. She 
may also invest in a co-specialized complementary asset, which might take the form of real estate in a trendy area. The restaurant concept, if successful, is likely to be imitated elsewhere, and may bring others to invest in the neighborhood, increasing the value of real estate in the area (Jacobides \& Winter, 2007). There is robust empirical evidence for the importance of owning or accessing complementary assets that are critical to clients for capturing value from innovation (Christmann, 2000; Desyllas \& Sako, 2013; McGahan \& Silverman, 2006).

Platform markets offer us an analogous setting through which to examine the issue of value capture by suppliers, or in this case, complementors (Gawer, 2009, 2014; Thomas, Autio, \& Gann, 2014). A technological platform is a modular system that creates value by generating economies of scope in supply (via sharing and re-use across products) and/or in demand (via network externalities). It is tempting to conclude that platform owners always capture the lion's share of the value generated, while complementors remain subsidiary. However, no platform owner can take its architectural leverage for granted, as complementors may compete and challenge its position, as Microsoft did to Netscape, and Facebook to Google (Gawer, 2014; Thomas et al., 2014). But just as GVC research focuses on lead firm strategy and under-explores supplier strategy, research on platforms has thus far focused on platform leader strategy rather than complementor strategy. Some have begun to recognize and address this gap (Sharapov, 2017). Complementor strategy consists of choosing a platform among competing platforms. It also consists of choosing appropriability regimes and controlling complementary assets as means to compete against other complementors. For digital platforms, leveraging complementary assets such as a proprietary software engine or algorithm, an established community of users of previous apps, and marketing support from third-party channels is critical to complementors capturing value.

We recommend wider use of Teece (1986)'s core constructs, especially appropriability regimes and complementary assets, by GVC scholars to uncover the conditions under which different types of upgrading at the firm-level lead to greater value capture and not just value creation. Controlling critical or appreciating specialized complementary assets is particularly important for capturing value when suppliers operate under weak regimes of appropriability. Below, we develop a framework to explain the choices available to suppliers to capture value, and to shape the governance mode of the value chain in which they operate. 


\section{SUPPLIER STRATEGY, GOVERNANCE AND VALUE CAPTURE IN GVCS}

This section presents an integrative theoretical framework that is, in effect, a decision tree for suppliers to analyze the implications of their strategic choices on governance and value capture. Table 1 summarizes ways in which corporate strategy improves the GVC theory of governance, and ways in which the profiting from innovation framework improves the utility of the existing upgrading typology. Our task is to pull these two strands into a unified framework (see Figure 1). For analytical purposes, we choose a captive supplier, Firm A, and consider how its strategic choices affect governance mode and the likelihood of capturing value from upgrading. This model attempts to hone in on a specifically undertheorized component of the broader GVC framework, namely supplier strategy.

\section{INSERT TABLE 1 AND FIGURE 1 ABOUT HERE}

(a) Supplier strategy. Firm A formulates its corporate strategy, a set of actions aimed at creating and sustaining competitive advantage. It assesses its external environment, the industry in which it operates (with rivals, suppliers, and buyers), and its internal resources and capabilities. Concretely, such corporate strategy involves decisions about two things: positioning in the value chain and buyer portfolio. If the firm is positioned in a GVC niche with high barriers to entry, it can capture a high percentage of the value it creates (see Figure 1). Expanding its capabilities may precipitate a shift from captive to other governance modes. However, supplier capabilities are a necessary but alone insufficient condition for enhancing supplier power. To do this, Firm A must choose to diversify its buyers. If it remains captive to a single buyer, it has limited profit potential. It is only by diversifying its buyer portfolio that a supplier facing low entry barriers might capture the value it creates by investing in upgrading.

(b) Value Capture. If Firm A enters a GVC niche with high barriers to entry, it can be relatively profitable from the beginning. By contrast, if the supplier enters a GVC segment with low barriers to entry, then the ability to capture the value created through upgrading depends on a number of additional factors. If Firm A decides to upgrade in a location with a robust appropriability regime and/or in a way that raises technical barriers to imitation, then it can capture the value it creates by upgrading without further considerations. If operating under weak appropriability regimes, Firm A can prevent imitation by investing in specialized complementary assets. Moreover, 
Firm A has a better chance of profiting from upgrading if it is in control of an asset which is critical to, or appreciating in value for the buyer (see Figure 1).

In order to contextualize the model, let us imagine that Firm A is an electronics contract manufacturer in an emerging economy, working for a large US-based branded electronics corporation, Firm B. Initially Firm B is Firm A's only client, so the governance mode is captive. Firm A can grow by building new production facilities in line with growing demand for Firm B's products. Firm A chooses to grow with its principal client, as Foxconn has done with Apple, for example. Governance is likely to remain 'captive' or shift to 'relational' if supplier capabilities increase. Alternatively, Firm A can scale up by diversifying its client base, as some American firms such as Flextronics and Jabil Circuit have done. Mode of governance can then shift to 'modular' or 'market'. But scaling up, whether undertaken on behalf of one or many buyers, offers limited opportunities to capture value. Firm A may create value on behalf of its client(s), but may capture little of it. This is because electronics contract manufacturing is subject to weak technological regimes of appropriability. The basic services provided are repetitive and highly codified, making suppliers highly substitutable.

Firm A can upgrade to higher value-added functions either upstream or downstream, as Taiwanese original design manufacturers (ODMs) have done. Functional upgrading could lead Firm A to shift from 'captive' to 'relational,' 'modular' or even 'market' governance. The decision of whether or not to diversify its buyers would yield different governance outcomes, with the shift to relational being more likely with a small number of buyers and the shift to modular or market being more likely with many buyers. All things equal, Firm A is more likely to shift governance mode if it diversifies its buyer portfolio. The main idea here is that Firm A can reconfigure its firm-level governance mode over time, rather than merely position itself in a pre-determined governance mode. Firm A could also leave contract manufacturing behind altogether, and become a branded firm, as Wistron and Pegatron did by spinning off Acer and ASUSTek, to varying results. This sort of functional upgrading is risky, not least because it involves suppliers turning into competitors for their clients. Nevertheless, sufficient evidence exists in this industry that a suppliers' ability to capture the value it creates varies from firm to firm, and depends on their strategic choice concerning their buyer portfolio.

GHS (2005) argue that as suppliers increase their capabilities, they drive shifts in GVC governance. Our analysis demonstrates that capabilities are necessary but alone insufficient for changing how dyadic transactions are governed. Suppliers must make decisions about 
whether they will remain captive to a single buyer, or codify their products and services to diversify their buyer portfolio. Diversifying to serve multiple buyers certainly requires developing capabilities (such as marketing capabilities) that a captive supplier may not need. However, we draw a distinction between the existence (or non-existence) of capabilities, and the decision regarding whether or not to develop and deploy them. Beyond a diversified buyer portfolio, suppliers can gain bargaining power relative to their clients by upgrading in strong regimes of appropriability, or upgrading while controlling critical or appreciating specialized complementary assets in weak appropriability regimes. These considerations in the supplier decision tree (Figure 1) are important in emerging markets, which tend to have weaker legal appropriability regimes and less established technology paradigms due to the prevalence of jugaad (frugal or low-cost) innovation (Govindarajan \& Ramamurti, 2011; Radjou, Prabhu, \& Ahuja, 2012).

\section{DISCUSSION}

Supplier strategy has received relatively little attention to date among GVC scholars. Much of the research on governance, whether one conceives of it as 'driving,' 'coordinating' or 'normalizing,' has focused on how lead firms direct resources, manage transactions or control discourse (Gibbon et al., 2008). And while certain elements of GVC theory, including the variable of supplier capabilities, lend themselves to a more serious examination of supplier strategy, there is as yet no guiding framework to describe and predict the situations in which increased capabilities will lead to changes in governance and value capture (Sturgeon, 2002). The framework presented here provides a systematic means of understanding the conditions under which suppliers are able to change the ways in which their relationships with buyer firms are governed, and further, how they are able to capture the value they create. The framework, though explained above in terms of the electronics industry, applies to various other industrial and service-oriented settings as well. Below, we interpret and discuss some of the empirical evidence in light of our framework. We start with cases of limited profit capture (the light grey boxes in Figure 2), followed by cases where suppliers have been able to capture profit (the dark grey boxes in Figure 2).

\section{INSERT FIGURE 2 ABOUT HERE}

The GVC literature attributes limited profit-earning potential to suppliers working in industry segments subject to low entry barriers. Our framework demonstrates that suppliers 
should pay attention to reasons other than low entry barriers if they are to protect their profitearning potential. Low entry barriers are common in supply markets with many interchangeable firms producing standardized products such as undifferentiated coffee and automotive wire harnesses. As pointed out by Kaplinsky and Morris (2001) and Mahutga (2014), without their own rare, valuable and inimitable resources (Barney, 1991), suppliers that improve their manufacturing processes, invest in product innovation, or take on more complex functions might find that their newly adopted practices diffuse easily. In the end, these investments end up being a means to simply keep pace with competitors rather than get ahead of them. Thus, when barriers to entry are low, investments in upgrading are simply the price of sustained admission to a GVC.

Electronic assembly is a market with low entry barriers, but buyer diversification and the control of specialized complementary assets have separate effects on profit earning potential. Taiwanese ODMs Inventec and Arima remained largely captive suppliers, and thus their investments in upgrading did little to change their position vis-à-vis their clients. Their increased capabilities may have shifted them from captive to relational governance, but there was no appreciable change in power vis-à-vis their clients. By contrast, Quanta and Compal diversified their client base and achieved greater success with faster growth and higher profitability than other ODMs (Kawakami, 2011). Nevertheless, weak appropriability regimes, coupled with their inability to access specialized complementary assets, meant that they captured a limited amount of the value they created (See Figure 2). These suppliers with a diversified buyer portfolio may have succeeded in shifting governance, but not in capturing significant value. What these cases demonstrate is that given the same constraints - these four suppliers are Taiwanese ODMs in the electronics industry - firms elect to pursue different strategies, which produce different outcomes.

A similar pattern can be observed in knowledge-intensive business services (KIBS), with global suppliers offering IT services (Holman, Batt, \& Holtgrewe, 2007) and other business functions (Gereffi \& Fernandez-Stark, 2010; Sturgeon \& Gereffi, 2009) including accounting, consulting, investment banking, and law (Sako, 2013). Suppliers in these GVCs are known as knowledge process outsourcing (KPO) providers, indicating a higher level of expertise and skills required to carry out judgement-based work, as compared to rule-based operations of business process outsourcing (BPO) providers (Sako, 2016). Just as contract manufacturers evolved into ODMs, undertaking both design and assembly, some India-based suppliers, such as Wipro, Infosys and Tata Consulting Services (TCS), have climbed up the value chain by shifting from being solely BPO providers to becoming KPO providers. These 
companies have also scaled their operations, investing heavily in digital technology and process improvements, and becoming multinational suppliers with a global presence. Finally, some have pursued a diversification strategy by bundling different professional services (e.g. financial research, market research, and legal support service) to create a one-stop shop for global corporate clients. The knowledge-intensive nature of professional services makes relational governance the most likely mode to be adopted; however, some differences in governance mode exist. Whether or not KPO providers capture the value they create through upgrading depends on their ability to protect their proprietary digital technology by filing patents and copyrights. Those that cannot, struggle to capture profits due to the absence of obvious critical complementary assets in the B2B services context. For instance, digital products and services do not rely on sales and distribution channels, an obvious complementary asset in a manufacturing setting (See Figure 2).

Next, we move on to discuss cases in which suppliers either erect barriers to entry from the beginning, or profit from upgrading by minding appropriability regimes and complementary assets, rather than by simply innovating faster than their competitors. One well-documented way that suppliers in bicycles (Fine, 1998; Galvin \& Morkel, 2001) and personal computers (Baldwin \& Clark, 2000; Gawer \& Cusumano, 2002) achieve this feat is by integrating key modules into their products and helping to shape the product architecture. MediaTEK, a Taiwanese chip-set design company, is a case in point. It developed a turnkey approach to mobile phone development, implanting its reference designs in various companies' handsets, whilst protecting its position as a platform leader by erecting entry barriers in the form of technological patents (Brandt \& Thun, 2011; Sturgeon \& Kawakami, 2011; Thun \& Sturgeon, forthcoming) (see Figure 2). Separate from the issue of platform leadership (Gawer \& Cusumano, 2002) and architectural leverage (Thomas et al., 2014), control of specialized complementary assets constitutes a means of achieving high profit earning potential. Suppliers decide which specialized complementary assets they wish to control by achieving what Kimura (2007) calls 'dynamic strategic fit' with buyers. This means that the supplier seeks to align its domain of activities with the lead firm's needs. Suppliers appropriate value by identifying and controlling specialized complementary assets critical to the lead buyer firm's operations.

The case of oil field services (OFS) is illustrative in this regard. The oil majors - firms like Shell, BP, and Exxon Mobil - did much of their own drilling until the 1980s, when the process became largely routine and simple. They began outsourcing the upstream segments of the value chain - principally exploration, appraisal, reserves development and production 
- to OFS providers (Lima de Oliveira, 2016; Tordo, Tracy, \& Arfaa, 2011). Over time, exploration and production became far more geologically complex. With the price of oil high in the early 2000s, producers began exploring more and more complex environments, like the pre-salt oilfields in Brazil. Many of the technological advances that enabled cost-effective exploration in previously inaccessible environments were driven by OFS providers like Schlumberger, Halliburton, Baker Hughes and Weatherford (Perrons, 2014). Today, some of these firms outspend the oil majors on $\mathrm{R} \& \mathrm{D}$ as a percentage of sales by a wide margin. As The Economist points out, "with hindsight, the oil companies' decision to outsource the grubby bits of the job looks like an opportunity squandered. It has also left the oil firms hostage to the availability of increasingly expensive and sought-after services, from advanced drilling to deep water rigs, which a dwindling number of OFS firms can provide" (Economist, 2012).

Schlumberger has inhabited the upstream segment of the value chain from the beginning, getting its start in geophysical surveying for mining and oil companies in the 1920s. The firm filed for a number of patents around its electrical coring technique early, allowing it to appropriate the value it created by offering its clients a richer picture of a certain area's oil reserves (Allaud \& Martin, 1977). The firm continues to invest in technological development under strong technical and legal regimes of appropriability, raising entry barriers for would be competitors (See Figure 2). Because of its increased technological complexity, drilling and well completion now account for two thirds of all expenditures on upstream activities (Lima de Oliveira, 2016). Further, OFS providers like Schlumberger now play an invaluable role supporting national oil companies (NOCs) like Pemex in Mexico and Petronas in Malaysia, state-owned firms with limited capabilities in the areas of seismic analysis, exploration and production. These suppliers offer their turnkey services to firms whose only reason for being is their hold on their countries' national oil reserves. As was previously suggested, the power a global supplier holds vis-à-vis an emerging-market client may lead to indeterminacy in governance. But in this industry, profit-earning potential resides with the suppliers because they operate within a strong appropriability regime.

Finally, the diamond industry provides a clear example of how a supplier, De Beers, continues to capture profit by creating and controlling valuable specialized complementary assets, even after the erosion in barriers to entry in mining and other segments of the diamond GVC. De Beers Consolidated Mines Ltd was created in 1888 as an instrument to consolidate the recently developed diamond mines of South Africa. It came to control the global supply 
of diamonds through a multinational cartel soon thereafter (Kretschmer, 2003). However, what allowed the company to turn a commodity into a valuable one was what Edward Epstein (1982) calls the 'diamond invention - the creation of the idea that diamonds are rare and valuable, and are essential signs of esteem.' De Beers' strategy of holding a stockpile of diamonds to control prices and to create a perception of scarcity, its control of wholesale and distribution channels, as well as its investments in advertising aimed at influencing public opinion ("A Diamond is Forever") allowed it to shape the industry's structure and capture the lion's share of profits. More recently, De Beers abandoned the stockpile in return for access to the US market. Moreover, the emergence of alternative sources of supply for diamonds undermined the company's monopolistic control over supply. Thus, De Beers' profit earning potential relies more and more on its complementary assets in the form of branding and downstream distribution networks in New York and Tokyo, but also in new locations such as China (AWDC \& Bain, 2016).

To summarize, the empirical vignettes chosen above provide evidence that if suppliers diversify their buyer portfolios, upgrade in the context of strong regimes of appropriability, and/or upgrade while in control of critical and appreciating specialized complementary assets, they can capture more power and value in the chain. Conversely, if suppliers face constraints that prevent them from doing any of the above, they face limited profit earning potential. In this way, this framework enables GVC researchers to classify industries (or locations) according to the availability (or absence) of potential buyers, appropriability regimes and complementary assets. The framework also enables us to analyze supplier strategy in relation to structural constraints over time. In the face of sustained structural constraints, we observe divergent supplier strategies, as we saw in the Taiwanese ODM industry. Over time, suppliers shift their strategy in response to changes in constraints, as illustrated by the cases of Schlumberger and De Beers. Moreover, our theoretical framework with a focus on supplier strategy has implications for value chain polarity. We identify the circumstances under which a supplier is likely to change the governance mode to which it is subject, and further, capture the value it creates by investing in upgrading. These preconditions can ultimately produce bipolar or multipolar value chains. However, this being a modular theory building effort focused on supplier strategy, we leave the work needed to connect firm-level action to changes in value chain polarity to future studies. 


\section{CONCLUSION}

The global value chain remains an alluring metaphor to describe one of the fundamental phenomena of economic globalization today. This study has sought to identify and develop several ideas that are either latent or absent in the GVC literature by focusing on supplier strategy. First, we engage with the concept of governance, arguing that suppliers can deviate from an industry's established form of governance. Taking the firm rather than the inter-firm linkage as the unit of analysis allows us to analyze suppliers' strategic decisions over firm boundaries and buyer portfolios. We acknowledge that a supplier's ability to internalize specific business functions depends on its buyer(s) being willing to externalize those same functions. However, we posit that in certain instances, suppliers do more than just maneuver within established boundaries. Over time, they can change the governance mode in which they operate to a varying degree, by diversifying their portfolio of buyers (sometimes across industries and geographies), and by reacting to opportunities provided by lead firms' strategic decisions (e.g. of outsourcing) and changes in institutional constraints (e.g. end of the Multi-Fiber Agreement). Otherwise stated, our model articulates ways in which supplier strategy enables them to redefine the nature of their relationships with buyers.

Second, we have sought to create tools to bridge the disjuncture between value creation and value capture. Profiting from upgrading requires more than just access to capital, technology and skills. It requires that firms recognize and mind appropriability regimes and specialized complementary assets, especially those that are either critical or appreciating in value. Numerous GVC scholars have argued that upgrading is not always a viable proposition for sustainable growth (Kaplinsky, 2000; Schrank, 2004; Ponte and Ewert, 2009). We articulate the circumstances under which value creation leads to value capture at the firm level by using Teece (1986)'s 'profiting from innovation' framework. We argue that suppliers, including complementors that use platforms, capture value they create by upgrading if they operate under strong appropriability regimes, or otherwise possess specialized complementary assets critical to their clients.

The integrative framework developed in this study has wide applicability in a broad range of industry and service settings. Our re-interpretation of existing company cases demonstrates that the profit earning potential of suppliers is realized as a result of their strategic choices. The framework is not static, but is best used in a dynamic setting in which suppliers are able to react to shifts in structural constraints. The underpinning theoretical thrust is the evolution over time in both agency and structural constraints so that (a) suppliers might originally operate as small dependent firms with structural constraints, (b) suppliers in 
the same industry facing the same constraints choose different strategies, and (c) some strategies emerge as being more successful than others because structural constraints might change in unpredictable ways over time, as the case of oil field services makes clear.

The model we have developed incorporates two strands of management theory corporate strategy and technology strategy - into the GVC framework. We have intentionally focused our analysis on suppliers in order to address the paucity of GVC research from the supplier perspective. Adopting the supplier strategy lens allows us to explore the space available to suppliers traditionally seen to be beholden to lead firm imperatives in buyerdriven GVCs. Such supplier strategy space is not just a matter of supplier capabilities but in part a matter of cognition, leading to different risk-taking decisions in relation to perceived constraints (Teece, 2014a). Our hope is that this work will encourage greater use of management theories by GVC scholars, so that we can draw clearer implications of firmlevel (and in particular supplier) strategies for clusters, economic development, the nature of North-South and South-South trade, and globalization. 


\section{REFERENCES}

Abernathy, W. J., \& Utterback, J. M. 1978. Patterns of industrial innovation. Technology review, 64: 254-228.

Allaud, L., \& Martin, M. 1977. Schlumberger: The History of a Technique. Toronto: John Wiley \& Sons.

Appelbaum, R. P. 2008. Giant transnational contractors in East Asia: emergent trends in global supply chains. Competition \& Change, 12(1): 69-87.

Argyres, N. S., \& Liebeskind, J. P. 1999. Contractual commitments, bargaining power, and governance inseparability: Incorporating history into transaction cost theory. Academy of Management Review, 24(1): 49-63.

AWDC, \& Bain. 2016. The Global Diamond Industry 2016: The Enduring Allure of Timeless Gems: Antwerp World Diamond Centre and Bain \& Company.

Bair, J., \& Gereffi, G. 2001. Local clusters in global chains: the causes and consequences of export dynamism in Torreon's blue jeans industry. World development, 29(11): 18851903.

Baldwin, C., \& Clark, K. B. 2000. Design Rules: The Power of Modularity. London: MIT Press.

Barney, J. 1991. Firm resources and sustained competitive advantage. Journal of Management, 17(1): 99-120.

Baron, D. P. 1995. Integrated strategy: Market and nonmarket components. California management review, 37(2): 47.

Bazan, L., \& Navas-Alemán, L. 2004. The underground revolution in the Sinos Valley: a comparison of upgrading in global and national value chains. Local enterprises in the global economy: Issues of governance and upgrading, 3: 110-139.

Berger, S. 2013. Making in America. Cambridge, Mass.: MIT Press.

Berger, S., \& Lester, R. K. 2005. Global Taiwan: Building competitive strengths in a new international economy: Routledge.

Brandt, L., \& Thun, E. 2011. Going mobile in China: shifting value chains and upgrading in the mobile telecom sector. International Journal of Technological Learning, Innovation and Development, , 4(1/2/3): 148-180.

Christmann, P. 2000. Effects of "best practices" of environmental management on cost advantage: The role of complementary assets. Academy of Management journal, 43(4): 663-680.

Coe, N. M., \& Yeung, H. W.-C. 2015. Global Production Networks: Theorizing Economic Development in an Interconnected World. Oxford: Oxford University Press.

Dedrick, J., Kraemer, K. L., \& Linden, G. 2009. Who profits from innovation in global value chains?: a study of the iPod and notebook PCs. Industrial and Corporate Change: dtp032.

Desyllas, P., \& Sako, M. 2013. Profiting from business model innovation: Evidence from Pay-As-You-Drive auto insurance. Research Policy, 42(1): 101-116.

Economist. 2012. The unsung masters of the oil industry. The Economist, 21 June.

Epstein, E. J. 1982. Have You Ever Tried to Sell a Diamond? The Atlantic, February issue.

Fine, C. H. 1998. Clockspeed: Winning Industry Control in the Age of Temporary Advantage. Reading, Massachusetts: Perseus Books.

Galvin, P., \& Morkel, A. 2001. The effect of product modularity on industry structure: the case of the world bicycle industry. Industry and Innovation, 8(1): 31-47.

Gawer, A. (Ed.). 2009. Platforms, Markets and Innovation. Cheltnam: Edward Elgar.

Gawer, A. 2014. Bridging differing perspectives on technological platforms: Toward an integrative framework Research Policy, 43: 1239-1249. 
Gawer, A., \& Cusumano, M. A. 2002. Platform Leadership. Cambridge MA: Harvard Business School Press.

Gereffi, G. 1999. International trade and industrial upgrading in the apparel commodity chain. Journal of international economics, 48(1): 37-70.

Gereffi, G. 2014. A global chain perspective on industrial policy and development in emerging markets. Duke Journal of International \& Comparative Law, 24: 434-458.

Gereffi, G., \& Fernandez-Stark, K. 2010. The Offshore Services Value Chain: Developing Countries and the Crisis, The World Bank Policy Resarch Working Paper 5262. Washington DC.

Gereffi, G., Humphrey, J., \& Sturgeon, T. 2005. The governance of global value chains. Review of International Political Economy, 12(1): 78-104.

Gereffi, G., \& Korzeniewicz, M. 1994. Commodity Chains and Global Capitalism. New York: Praeger.

Geroski, P. 2003. The evolution of new markets: Oxford University Press.

Gibbon, P., Bair, J., \& Ponte, S. 2008. Governing global value chains: an introduction. Economy and Society, 37(3): 315-338.

Gibbons, R. 2005. Four formal(izable) theories of the firm. Journal of Economic Behavior \& Organization, 58: 200-245.

Giuliani, E., Pietrobelli, C., \& Rabelotti, r. 2005. Upgrading in Global Value Chains: Lessons from Latin American Clusters. World Development, 33: 549-573.

Govindarajan, V., \& Ramamurti, R. 2011. Reverse innovation, emerging markets, and global strategy. Global Strategy Journal, 1(3-4): 191-205.

Guerrieri, P., \& Pietrobelli, C. 2004. Industrial districts' evolution and technological regimes: Italy and Taiwan. Technovation, 24(11): 899-914.

Henderson, J., Dicken, P., Hess, M., Coe, N., \& Yeung, H. W.-C. 2002. Global production network and the analysis of economic development. Review of International Political Economy, 9(3): 435-464.

Holman, D., Batt, R., \& Holtgrewe, U. 2007. The global call center report: International perspectives on management and employment[Electronic version]. Ithaca, NY.

Humphrey, J., \& Schmitz, H. 2000a. Governance and upgrading: linking industrial cluster and global value chain research: Institute of Development Studies Brighton.

Humphrey, J., \& Schmitz, H. 2000b. Governance and upgrading: linking industrial cluster and global value chain research. Brighton: Institute of Development Studies.

Humphrey, J., \& Schmitz, H. 2002. How does insertion in global value chains affect upgrading in industrial clusters? Regional studies, 36(9): 1017-1027.

Islam, M. S. 2008. From pond to plate: towards a twin-driven commodity chain in Bangladesh shrimp aquaculture. Food Policy, 33: 209-223.

Jacobides, M. G. 2008. How capability differences, transaction costs, and learning curves interact to shape vertical scope. Organization Science, 19(2): 306-326.

Jacobides, M. G., Knudsen, T., \& Augier, M. 2006. Benefiting from innovation: Value creation, value appropriation and the role of industry architectures. Research Policy, 35(8): 1200-1221.

Jacobides, M. G., \& Winter, S. G. 2007. Entrepreneurship and firm boundaries: The theory of A firm. Journal of Management Studies, 44(7): 1213-1241.

Kaplinsky, R. 2000. Globalisation and unequalisation: What can be learned from value chain analysis? Journal of Development Studies, 37(2): 117-146.

Kaplinsky, R., \& Morris, M. 2001. A Handbook for Value Chain Research. IDRC.

Kawakami, M. 2011. Inter-firm dynamics in notebook PC value chains and the rise of Taiwanese original design manufacturing firms. In T. Sturgeon, \& M. Kawakami (Eds.), The Dynamics of Local Learning in Global Value Chains: 16-42: Springer. 
Kimura, S. 2007. The Challenges of Late Industrialization: The Global Economy and the Japanese Commercial Aircraft Industry. New York: Palgrave Macmillan.

Kretschmer, T. 2003. De Beers and Beyond: The History of the International Diamond Cartel. New York University. New York: New York University.

Lima de Oliveira, R. 2016. Resource-Led Industrial Development in the Oil \& Gas Supply Chain: The Case of Brazil, MIT-IPC Working Paper Series 16-002.

Mahutga, M. C. 2012. When do value chains go global? A theory of the spatialization of global value chains. Global Networks, 12: 1-21.

Mahutga, M. C. 2014. Global models of networked organization, the positional power of nations and economic development. Review of International Political Economy 21(157-194).

McGahan, A. M., \& Silverman, B. S. 2006. Profiting from technological innovation by others: The effect of competitor patenting on firm value. Research Policy, 35(8): $1222-1242$.

Mudambi, R. 2007. Offshoring: economic geography and the multinational firm. Journal of International Business Studies, 38(1): 206.

Pache, A.-C., \& Santos, F. 2010. When worlds collide: the internal dynamics of organizational responses to conflicting instittional demands. Academy of Management Review, 35(3): 455-476.

Peng, M. W., Wang, D. Y. L., \& Jiang, Y. 2008. An institution-based view of international business strategy: a focus on emerging economies. Journal of International Business Studies, 39: 920-936.

Perrons, R. K. 2014. How innovation and R\&D happen in the upstream oil \& gas industry: Insights from a global survey. Journal of Petroleum Science and Engineering, 124: 301-312.

Pisano, G. 2006. Profiting from innovation and the intellectual property revolution. Research Policy, 35(8): 1122-1130.

Ponte, S. 2014. The evolutionary dynamics of biofuel value chains: from unipolar and government-driven to multipolar governance. Environment and Planning, 46: 353372.

Ponte, S., \& Sturgeon, T. 2014. Explaining governance in global value chains: A modular theory-building effort, Review of International Political Economy, 21(1): 195-223.

Prahalad, C. K., \& Hamel, G. 1990. The core competence of the corporation. Harvard Business Review, 68(3): 79-91.

Radjou, N., Prabhu, J., \& Ahuja, S. 2012. Juggard Innovation: Think Frugal, Be Flexible, Generate Breakthrough Growth. San Francisco: Jossy-Bass.

Ramamurti, R., \& Singh, J. V. (Eds.). 2009. Emerging Multinationals in Emerging Markets. Cambridge: Cambridge University Press.

Sako, M. 2011. Driving power in global supply chains. Communications of the ACM, 54(7): 23-25.

Sako, M. 2013. Professionals between market and hierarchy: a comparative political economy perspective. Socio-Economic Review, 11(1): 185-212.

Sako, M. 2016. Professional skills: impact of comparative political economy. In J. Buchanan, D. Finegold, K. Mayhew, \& C. Warhurst (Eds.), Oxford Handbook of Skills and Training. Oxford: Oxford University Press.

Schmitt, A., \& Van Biesebroeck, J. 2016. In-house production versus specific forms of supplier governance: testing predictions of the global value chains model. International Journal of Automotive Technology and Management.

Schmitz, H. 1999. Global competition and local cooperation: success and failure in the Sinos Valley, Brazil. World development, 27(9): 1627-1650. 
Schrank, A. 2004. Ready-to-wear development: foreign investment, technology transfer, and learning by watching in the apparel trade. Social Forces, 83(1): 123-156.

Scott, R. W. 2001. Institutions and organizations. Thousand Oaks: Sage Publications.

Sharapov, D. 2017. Complementor Strategies in Smartphone Application Markets: a Configurational Perspective: DRUID conference paper.

Sturgeon, T. 2002. Modular production networks: a new model of industrial organization. Industrial and Corporate Change, 11(3): 451-496.

Sturgeon, T., \& Gereffi, G. 2009. Measuring success in the global economy: international trade, industrial upgrading, and business function outsourcing in global value chains. Transnational Corporations, 18(2): 1-35.

Sturgeon, T., Van Biesebroeck, J., \& Gereffi, G. 2008. Value chains, networks and clusters: reframing the global automotive industry. Journal of economic geography, 8(3): 297-321.

Sturgeon, T. J., Humphrey, J., \& Gereffi, G. 2011. Making the global supply base. In G. Hamilton, M. Petrovic, \& B. Senauer (Eds.), Market Makers: How Retailers and Reshaping the Global Economy. Oxford: Oxford University Press.

Sturgeon, T. J., \& Kawakami, M. 2011. Global value chains in the electronics industry: characteristics, crisis, and upgrading opportunities for firms from developing countries. International Journal of Technological Learning, Innovation and Development, 4(1-3): 120-147.

Sturgeon, T. J., \& Lester, R. 2004. The new global supply-base: new challenges for local suppliers in East Asia. In Y. Shahid, M. A. Altaf, \& K. Nabeshima (Eds.), Global Production Networking and Technological Change in East Asia. Oxford: Oxford University Press.

Teece, D. J. 1986. Profiting from technological innovation: Implications for integration, collaboration, licensing and public policy. Research Policy, 15: 285-305.

Teece, D. J. 2014a. A dynamic capabilities-based entrepreneurial theory of the multinational enterprise. Journal of International Business Studies, 45(1): 8-37.

Teece, D. J. 2014b. The foundations of enterprise performance: dynamic and ordinary capabilities in an (economic) theory of firms. Academy of Management Perspective, 28(4): 328-352.

Teece, D. J., Pisano, G., \& Shuen, A. 1997. Dynamic capabilities and strategic management. Strategic Management Journal, 18(7): 509-533.

Tewari, M. 2008. Varieties of global integration: navigating institutional legacies and global networks in India's garment industry. Competition \& Change. Competition \& Change, 12(1): 49-67.

Thomas, L. D. W., Autio, E., \& Gann, D. M. 2014. Architectural leverage: putting platforms in context. Academy of Management Perspective, 28(2): 198-219.

Thun, E., \& Sturgeon, T. forthcoming. When global technology meets local standards: reassessing the China's mobile telecom policy in the age of platform innovation. In L. Brandt, Thomas, \& Rawski (Eds.), The Impact of Industrial Policy and Regulation on Upgrading and Innovation in Chinese Industry.

Tokatli, N. 2013. Towards a better understanding of the apparel industry: a critique of the upgraidng literature. Journal of Economic Geography, 13(6): 993-1011.

Tordo, S., Tracy, B. S., \& Arfaa, N. 2011. National Oil Companies and Value Creation, World Bank Working Paper 2018. Washington DC.

Tran, N., Bailey, C., Wilson, N., \& Phillips, M. 2013. Governance of global value chains in response to food safety and certification standards: The case of shrimp from Vietnam. World development, 45: 325-336. 
Tripsas, M. 1997. Unraveling the process of creative destruction: Complementary assets and incumbent survival in the typesetter industry. Strategic Management Journal, 18(Special issue): 119-142.

Whittaker, D. H., Zhu, T., Sturgeon, T., Tsai, M. H., \& Okita, T. 2010. Compressed Development. Studies in Comparative International Development, 45: 439-467.

Williamson, O. E. 1975. Markets and hierarchies: Analysis and antitrust implications. New York: The Free Press.

Williamson, O. E. 1985. The economic institutions of capitalism. New York: The Free Press.

Xu, D., \& Shenkar, O. 2002. Institutional distance and the multinational enterprise. Academy of Management Review, 27(4): 608-618. 
Table 1. Modifying the GVC Framework to Account for Supplier Strategy

\begin{tabular}{|c|c|c|c|c|}
\hline Concepts & $\begin{array}{l}\text { Existing } \\
\text { typology }\end{array}$ & Critique & $\begin{array}{l}\text { Management } \\
\text { theory }\end{array}$ & Modified theory \\
\hline Governance & $\begin{array}{l}\text { Buyer-driven vs. } \\
\text { producer-driven; } \\
\text { market vs. } \\
\text { hierarchy with } \\
\text { three network } \\
\text { forms in between }\end{array}$ & $\begin{array}{l}\text { Does not theorize } \\
\text { about make-or- } \\
\text { buy decision or } \\
\text { client portfolio } \\
\text { from a supplier's } \\
\text { perspective }\end{array}$ & $\begin{array}{l}\text { Corporate } \\
\text { strategy }\end{array}$ & $\begin{array}{l}\text { Corporate } \\
\text { strategy relating } \\
\text { to firm } \\
\text { boundaries and } \\
\text { buyer portfolio } \\
\text { are coterminous } \\
\text { with governance } \\
\text { decisions }\end{array}$ \\
\hline Upgrading & $\begin{array}{l}\text { Product, process, } \\
\text { functional, inter- } \\
\text { sectoral } \\
\text { upgrading or } \\
\text { downgrading }\end{array}$ & $\begin{array}{l}\text { Does not theorize } \\
\text { the circumstances } \\
\text { under which } \\
\text { value creation } \\
\text { (through } \\
\text { upgrading) leads } \\
\text { to value capture }\end{array}$ & $\begin{array}{l}\text { Profiting from } \\
\text { innovation } \\
\text { framework }\end{array}$ & $\begin{array}{l}\text { Capturing value } \\
\text { from upgrading } \\
\text { by assessing stage } \\
\text { of technology } \\
\text { development, } \\
\text { appropriability } \\
\text { regime, and } \\
\text { possibility of } \\
\text { investing in } \\
\text { complementary } \\
\text { assets }\end{array}$ \\
\hline
\end{tabular}


Figure 1. Supplier Decision Tree

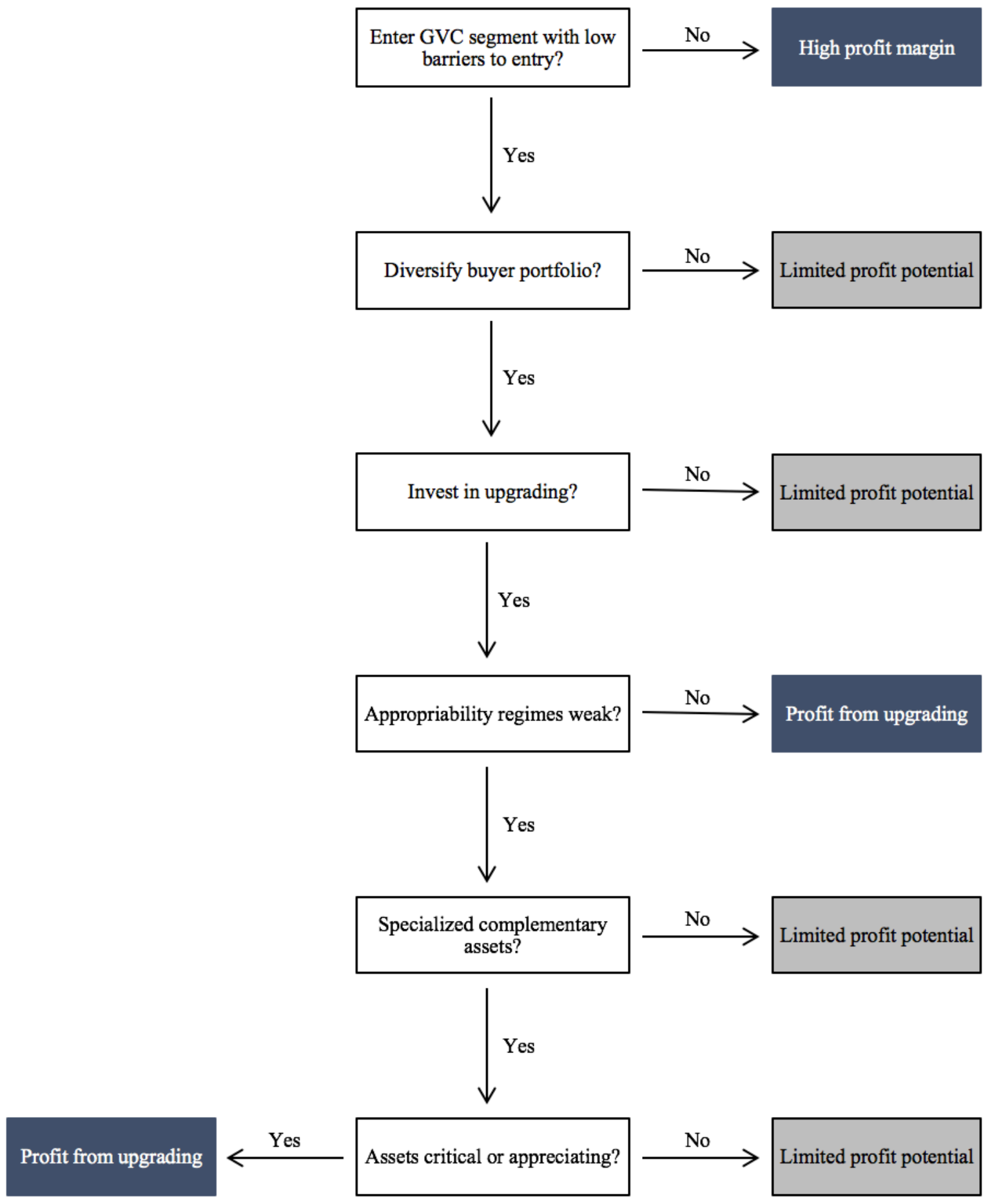

Source: Authors, based on Teece (1986) and Jacobides et. al. (2006). 
Figure 2. Supplier Decision Tree Overlaid with Company Cases

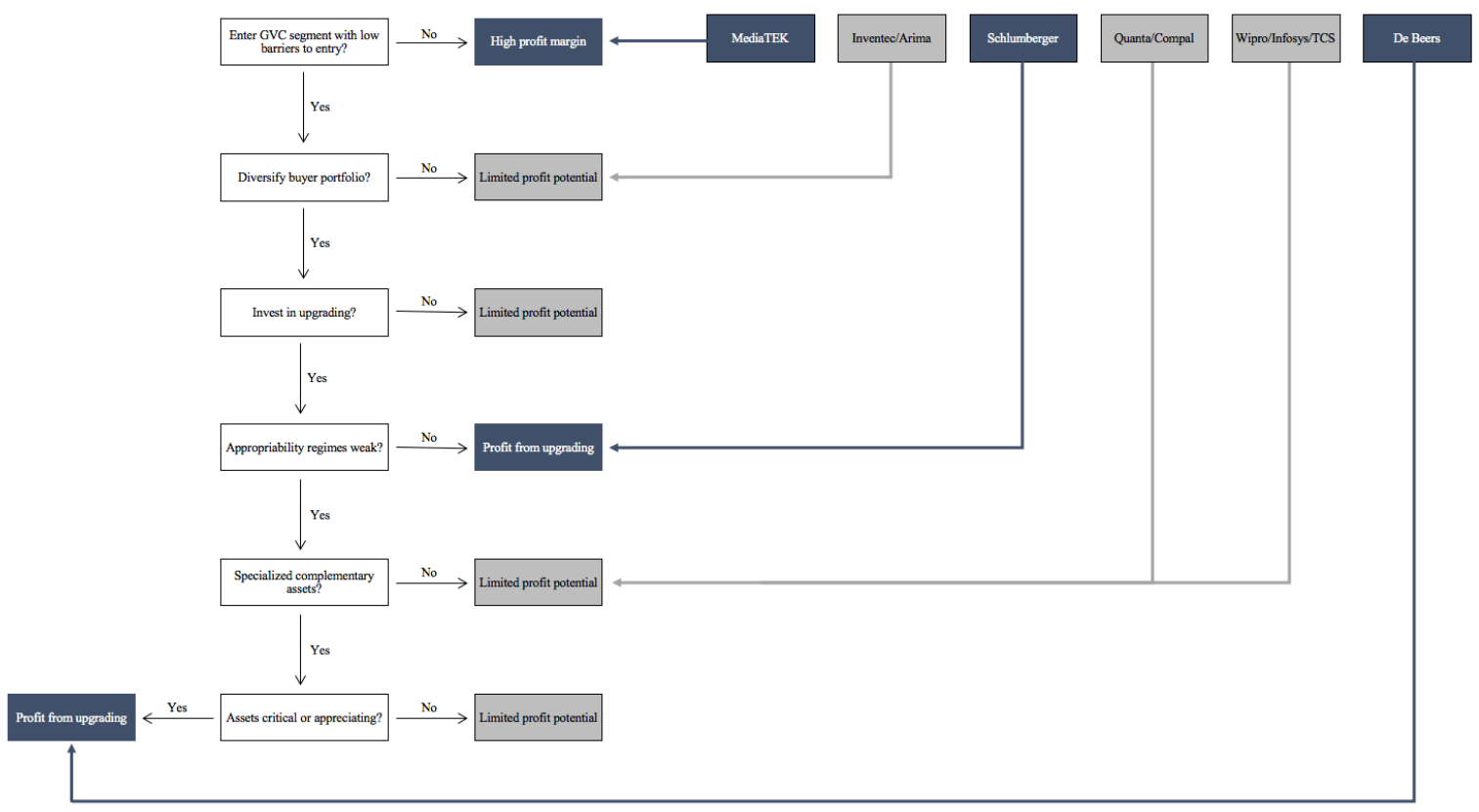

Note: Companies in light grey boxes faced limited profit potential; companies in dark grey boxes were able to profit from upgrading. 